\title{
A Whole New World of Freaks and Geeks: Libraries and Librarians on YouTube
}

\author{
Eric Poulin \\ Greenfield Community College \\ One College Drive \\ Greenfield, MA 01301 \\ pouline@gcc.mass.edu
}

\begin{abstract}
Media content analysis studies have historically focused on the portrayal of librarians on television and film. However, with the recent popularity of YouTube, there is an emerging, end-user created media that has not been thoroughly analyzed for its treatment of our profession. It is discovered that portrayals of libraries and librarians on YouTube are almost exclusively negative, raising the question whether efforts to combat negative librarian stereotypes have been effective.
\end{abstract}

\section{INTRODUCTION}

Over the years, there have been a number of studies conducted in an attempt to analyze how both libraries and librarians are portrayed in the mass media, and how these images influence public perception of the profession. The majority of these studies focused upon film and television, and attempted to analyze images of librarians and how these representations could potentially lead to development and perpetuation of various stereotypes.

We are now at a unique time in our cultural history, however, as an increasingly large (and ever growing) percentage of our entertainment and information media is actually being created by independent end-users. The proliferation of multiple Web 2.0 formats-blogs, wikis, social networks, etc.-are creating an environment where not only are end-users being influenced by the content that they are consuming, but they are also able to exert their own independent influence upon the content. Clearly, we are moving towards an increasingly "cool" media that Marshall McLuhan theorized, one that is extremely high in user participation (McLuhan, 1964).

YouTube is an example of such an application. Founded in 2005, it is a site that allows users to post and view videos without downloading any additional software. Ease of use as well as an overall feel of a cutting-edge, free-for-all environment (videos are not pre-screened before being posted although pornography and overly sexual material is not allowed) has been a large contributing factor to its dramatic rise in popularity. As of May 2008, it was the third most popular website in the world, 
according to Alexa, a company that monitors Internet traffic to other websites. In 2006, the site was purchased from its founders by Google for $\$ 1.65$ billion (Cloud, 2006).

With such a large number of videos independently created and posted to YouTube (a study conducted by ComScore another Internet-usage monitoring company, determined that 100 million videos were streamed from YouTube in July 2006 (Comscore, 2006)), the argument could certainly be made that this site is now part of the mass, albeit nontraditional, media. This leads to the question of how libraries and librarians are being depicted in this relatively new medium. YouTube content (posted by independent end-users), one could speculate that we could truly determine what the general public (or at least those who are web-savvy enough to create YouTube content) believes about libraries, librarians, and the profession in general.

This paper will therefore pose three research questions:

1. What are the images associated with libraries and librarians on YouTube?

2. How do they differ (if at all) from images that are present on television or in film?

3. How can we use these discoveries to gain a better understanding of the perceptions of the public towards our profession?

\section{LITERATURE REVIEW}

As was previously stated, the analysis of media content and how it relates to librarians is not a new endeavor. Historically, librarians have been unhappy with the manner in which they have been portrayed in the traditional mass media. However, recent literature seems to indicate that there is an increasingly higher percentage of positive images of librarianship in television and film. The 2007 documentary "The Hollywood Librarian" presented dozens of clips of feature films that illustrate the wide array of portrayals of librarians, both positive and negative. These clips were interwoven with interviews with a number of actual librarians, in an attempt to shed greater light upon what professionals in the field are accomplishing on a daily basis. By its very nature, this film should be viewed as a positive portrayal of librarianship, and an attempt to overcome some of the stereotypes that exist about the profession although the fact that it was produced by the American Library Association is clearly an inherent bias.

In her 2008 study, Maura Searle assesses that there are five specific librarian stereotypes that can be found in the mass media: "the Old Maid Librarian" (the most traditional, glasses and hair in a bun image), "the Policeman Librarian" (the overzealous, authoritative figure), "the Librarian as Parody" (citing Parker Posey's character in "Party Girl" and Nancy Pearl's "shushing librarian" action figure as examples), "the Inept Librarian" (socially awkward characters who require the reclusiveness of a quiet library), and "the Hero/ine Librarian" (Rupert Giles of "Buffy The Vampire Slayer" was the example cited). She also notes that while the general public's perceptions of librarians are generally positive, these stereotypes fail to inform viewers of the types of responsibilities that librarians perform. The end 
result is that there is very little knowledge of the work, skills, and education of librarians (Searle, 2008). This assessment is confirmed by Jody Fagan's study of undergraduates' perceptions of academic librarians, where it was discovered that students had little knowledge of the skills and educational background required to be a librarian (Fagan, 2002).

Many studies cite variations of the Old Maid Librarian and the history and progression of the stereotype. Katherine Adams believes that the best way to combat this stereotype is for modern librarians to actually embrace it, "in order to diffuse and disarm the power dynamic that created (it) in the first place." She notes that multiple groups have used this practice in various contexts, including African Americans reclaiming the " $\mathrm{N}$ " word, and gays and lesbians embracing the term "queer" (Adams, 2000). Holly Riccio also seems to believe this to some extent, citing the widespread popularity of the Nancy Pearl Librarian Action Figure as indication that the profession is comfortable enough in its own skin to be able to poke fun at itself (Riccio, 2004).

Marie and Gary Radford take a somewhat similar approach to their study of the film "Party Girl." They apply Stuart Hall's cultural studies approach to their analysis of the film in an attempt to help viewers "read" stereotypical images of librarians in the mass media. They summarize Hall's work citing that he believes that culture is defined by its shared meanings that representation is "the production of meaning through language" (Hall, 1997). They go on to say that "meaning is culturally produced and is constantly being produced and exchanged in every personal and social interaction in which we take part" (Radford, 2003).

There are two distinctly opposite stereotypes positioned against each other in the movie "Party Girl" the ("Old Maid") librarian stereotype, and the "Party Girl" stereotype. They believe that by having one specific character embrace both stereotypes over the course of the movie challenges both images. They assert that Hall believes that there are three approaches to challenging stereotypes: reversing the stereotype (portraying librarians as young and hip, which does occur in "Party Girl"), substituting a range of positive images for the negative ones that exist in popular representation, or by contesting the stereotype from within (by conceding that representation is constantly in flux, and that meaning is never truly fixed). Radford and Radford cite the "working from within the stereotype" approach in websites like "The Lipstick Librarian" (Absher, 2008) and the "Warrior Librarian Weekly" (Credaro, 2008).

More general studies of how librarians are portrayed in movies and television have discovered that a certain amount of progress has been made in recent years. Beth Yeagley asserts that negative characteristics like wearing hair in a bun and shushing patrons have virtually disappeared from the screen (Yeagley, 1999). The development of characters like Noah Wyle in the film "The Librarian," and Rupert Giles from the television series "Buffy the Vampire Slayer" seems to present a new image of librarians (Grace Anne DiCandido wrote that Giles "has done more for the image of the profession than anything in the past 50 years" (Dicandido, 1999)). While still somewhat socially awkward, these characters are able to use the librarian stereotype in a positive fashion, saving the world from imminent peril at the hands of evil through their ability to access and use information quickly and accurately (Kniffel, 2005). These are examples of Searle's "Hero/ine Librarian." 
It is noteworthy to point out that these two depictions often cited as being the two most positive portrayals of librarians in years are both men. Historically, the vast majority of librarians on film and television have been women, and the few men that have made their way onto the screen have been generally negative portrayals (Yeagley, 1999). Librarianship has been perceived as a "feminized profession" for the last 100 or so years (although it had previously been a field that had employed almost exclusively men specifically during the 1800s). Likewise, the male librarian stereotype has been that of a "kindly and sometime effeminate misfit" (Dickinson, 2002). It appears that this stereotype has shifted to a more masculine figure from a film and television media perspective although the reason behind this is unclear. The vast majority of professional librarians in the field are still female, so there has not been a tremendous influx of dashingly handsome new male librarians from which to cull this imagery.

A survey of the professional literature about YouTube finds that librarians have written guides to assist other users with ways to utilize this application to promote their library and its services (Webb, 2007). Other studies have examined YouTube from a cultural studies perspective focusing on how users engage with YouTube and vice-versa (Trier, 2007). To the best of the author's knowledge, no one has focused on studying how librarians and libraries are depicted in this new format.

\section{CONTENT ANALYSIS}

The dynamic nature of YouTube itself presents a challenge when attempting to conduct a content analysis survey. As end-users are able to freely post content, they are also able to remove content without any prior warning to viewers. A content analysis conducted one day could potentially become completely obsolete the next as new videos are added and removed daily. For the purposes of this study, analysis is limited to the sample of content that was available on YouTube during May 2008.

Films that are clearly produced by libraries or librarians, as well as clips that had previously aired in different formats, were not included in the study. One can safely assume that librarians are interested in presenting as positive an image of their profession as possible. Therefore, this inherent bias was viewed as being a factor that would have too great of an influence upon the sample to be able to use. In addition, YouTube clips that were posted as excerpts of films, television programs, or commercials were also disqualified. The nature of the study was to examine films that were created independently with the clear intent of being posted to YouTube.

A search for the word "librarian" conducted on May 23, 2008 yielded a result of "about 2,410" videos. While a great many of these clips on the initial results page were excerpts of feature films and television (clips from the motion pictures Party Girl, The Music Man, UHF, and The Hollywood Librarian are featured, as well as the classic Monty Python "Gorilla Librarian" skit), many independent short films could also be found. The percentage of independent films per page subsequently increased as the searcher proceeded on to further results page. And how were librarians portrayed on the whole in these films? The results were quite surprising. The traditionally stereotypical "glasses-and-bun-wearing loveless frump" female librarian image that has permeated throughout our popular culture for nearly a 
century was essentially non-existent. In fact, the percentage of films that featured female librarians in general was actually and shockingly quite small.

Rather, the YouTube library seems to be employed predominantly by men-often an obsessive compulsive disorder-filled enforcer who takes his job far too seriously (like Searle's "Policeman Librarian"), and who at times can have a rather violent or maniacal streak. The female librarians that are featured are not sexually-repressed middle-aged dowdy women, but are rather highly sexuallycharged, and seem to be clearly present only to be objectified to the point where there are occasionally targeted for some extremely degrading actions. And on the whole, the library as a place appears to be a soulless, authoritarian center where the only fun occurs when pranks or inappropriate behavior takes place.

\section{The Male YouTube Librarian}

While it should be mentioned that a great many of these videos are comic spoofs or "mockumentaries," a quick perusal of male librarians on YouTube introduces us to a wide array of social misfits, powertrippers, and psychos. There's "Erik the Librarian," a seemingly-brilliant, but socially inept reference librarian, whose inability to hold a simple conversation without frightening off his patrons seems to hinder his ability to conduct a thorough reference interview. There 'is the eponymous character in a film called "Angry Librarian" who (according to the film's description) is a "frustrated state employee who gives a spacey girl a hard time." While the film's title is a bit misleading--he certainly is not "angry"his condescending attitude and reluctance to assist the patron make him nearly a paradigm of how not to deal with members of the public. One librarian actually responded with a request be able to use the film in a customer service training program.

Then there are the staff in "The Librarian Dialogues" an overzealous group of micromanagers who treat the issue of how to deal with theft of library VHS tapes with a level of grave importance leads you to believe that solving this dilemma was as crucial as finding a cure for cancer. The main character in a film simply titled "The Librarian" (a funny and actually quite touching short that seems to be inspired by the television show "The Office") claims that he is not a boring individual although this statement is quickly followed by his guided tour of the rolls of tape that the library uses for book repair ("extra strength and regular strength").

As far as overzealousness, there is no shortage of male librarians who take their job duties to an enforcer's level. There is the character Larry Lovell, a Drake University Law Librarian, whose authoritarian approach to running his library has cleaned out the "murder, gangs, prostitution, drugs, and more" that had formerly run amok there (at one point, Larry repeatedly bangs his fist onto his desk, screaming into the camera about how his degree in library science makes him unable to stand for the lawlessness). There is "Bill Hutkins, Library Cop," a bumbling, but strangely lovable security guard, whose no-nonsense, tough-as-nails approach to protecting his patrons (one young female patron in particular) ultimately costs him the job that he holds so dear to his heart.

The "Ninja Librarian" will not tolerate any noise or cell phone usage in his library swiftly responding to offenders with a martial arts attack. Overdue books are also dealt with in a violent manner in a short 
called "Library? Security? Dancing Girls" (starring a librarian and a security guard both seeking the affections of a young woman who is interested in being hired for both of their respective positions).

Similarly, the title character in the film "Library Security Guard" deals with offenses like talking in the high school library or overdue books in an overly-violent manner. Meanwhile, a short simply called "Librarian" (posted by Doris Films) plays out like a drug-deal-gone-bad scenario where a patron has overdue books, and ends up pulling a gun on a character called the "Library Enforcer."

Male librarians also seem to have a bit of a psychotic murderer-streak in them, as evidenced by several featured films. "Crazy Librarian" features a wig-wearing eponymous character who murders students who violate library policies. There is another librarian-murderer featured in a short called "The Librarian" who becomes similarly enraged at such offenses as overdue books. Yet another film titled "The Librarian" features a vampire librarian who lures his victims in by offering reference and reader's advisory service, only to seize the opportunity to attack them, drinking their blood in the process.

\section{The Female YouTube Librarian}

While the male librarians on YouTube seem to be flawed in their overzealous commitment to their work, their female counterparts (the few that are portrayed) seem to take no interest whatsoever in the traditional roles and duties of the library. Rather, they seem to exist as sexual entities although their level of empowerment seems to vary from film to film. At times they are in charge of their sexuality, like the attractive librarians in the video titled "Librarian" (posted by Haunted Love), who seem to be intent on seducing a male patron, only to end up crushing him between two movable stacks. The title characters in a short titled "Sexy Librarians" end up turning the tables on a couple of young male patrons who go to the library with the intention of having "sexual intercourse with those physically unattractive librarians" in order to have their fees waived. The librarians become aware of the intentions of their naïve pursuers, and decide to become the physical aggressors in order to expose the inexperience of the young men. In the end, their plan is foiled, and the boys end up leaving the library in shame.

The female librarians in other films are not quite as fortunate, as they are often viewed in a voyeuristic and objectifying manner. The film "Hails is a Sexy Librarian" is a one-minute posing session by a young woman in a bikini, and actually makes no reference to libraries or librarianship at all (the same young woman appears in another film titled "Sexy Librarian") where she discusses, among other things, her new job at a bookstore, a position which apparently qualifies her to refer to herself as a librarian.

Other films are camera phone-shot voyeuristic movies focused on specific body parts of unaware women. A short called "Librarian: Heel Lift, A Quick View" is a minute-long shot of a woman working at a desk in a library, and seems to be an attempt to appeal to the foot-fetishist audience. This particular group is would also be interested in a six-film series dedicated to exposed feet ("Baresoles in the Library"). Meanwhile, the film "Hot Miami Librarian" is actually no more than a 13-second long close-up of a woman's backside! 
Finally, and perhaps the most disturbing film that was observed was titled "Hot Sexy Librarians Getting Peed On". The "plot" revolves around a man who is attempting to study in a library, and is constantly being disturbed by two women who are having a conversation. The man decides to deal with the situation by urinating in their faces, and then asking if they would "keep it down," as he has a really big test upcoming for which he is studying. The women do not object to the urination, and actually comply happily with his request for quiet!

\section{The Library as a Place}

A YouTube search for the word "library" on May 30, 2008 yielded about 55,100 results. A great many of these videos are real-life scenarios where pranks are conducted in the library. A film called "Library Porno" is a prank pulled on an unaware patron ("Ernie" the roommate of the filmmakers), where pornographic books are stashed in his bag while he is assisting another student. Poor Ernie also has the misfortune of trying to power down his laptop unaware that his filmmaking roommates have loaded a highly inappropriate shutdown audio onto the hard drive.

More creative is a film called "Prangstgrup Library Musical - Reading on a Dream PRANK!!" where two students get up in the middle of a quiet and crowded library study room and break out into a Broadway musicalesque song. Finally, the library at the University of Kentucky seems to be the most popular spot for YouTube pranks, as multiple films have been shot at that location including one where a student rappels down from one floor to another, landing among his studying peers.

There is also no shortage of non-prank related videos where behavior that would be deemed unusual for a library is featured. For example, a student takes a poll of his peers to discover where would potentially be the best place to have sex in the UCSB Library ("Sex in the Library") a topic that seems to come up in multiple films. Random heavy-metal guitar playing in quiet libraries also seems to be an endeavor that occurs on numerous occasions in a variety of videos.

\section{YouTube Librarians versus Television and Film Librarians}

Clearly, there are some very stark differences in the portrayals of librarians on television and film, as opposed to YouTube. While analysis of traditional electronic mass media could lead us to believe that stereotypes of librarians are being combated and overcome, the argument can now be made that a new batch of equally-unflattering images is currently developing. Male librarians are as socially-awkward as ever with a new, maniacal and psychotic twist added. Female librarians exist not as information professionals, but rather as objects for the voyeuristic to enjoy.

Given the commitment that we as a profession have made concerning our professional image, this is a sobering discovery, indeed. It could possibly be argued that this is not truly a reflection of the population's perceptions of librarians; that this content is being created exclusively by those who are tech-and-web-savvy enough to create YouTube films, which does not accurately reflect a true crosssection of the general population. Nonetheless, by discovering such a nearly-unanimously-negative sample of librarians and libraries on YouTube, one cannot deny that a substantial portion of the population must hold a negative view of our profession and are perpetuating this view via this 
application. Clearly, by its very nature of being a user-driven medium, and such a popular one at that, we must give some acknowledgement to these depictions of our profession as being worthy of our consideration and discussion.

Further, one could make a general assumption that these tech-literate end-users that are creating this content are most likely on the younger side probably those who have always lived with technology, and are able to adapt to new applications quickly. If this is indeed true, we have to ask very seriously if our attempts to raise our public image have failed with the next generation.

\section{Conclusion}

This paper seeks to answer three research questions:

1. What are the images associated with libraries and librarians on YouTube?

2. How do they differ (if at all) from images that are present on television or in film?

3. How can we use these discoveries to gain a better understanding of the perceptions of the public towards our profession?

It was discovered that nearly all depictions of libraries and librarians that were created and posted to YouTube by independent end-users were negative. This discovery is in opposition to recent literature that states that images of librarians on television and film are becoming increasingly positive. The question was posed regarding the user-created nature of YouTube, and whether or not it does accurately represent the views of a wide cross-section of the population. It was concluded that by its very nature of being a "cool" medium, that the portrayals and stereotypes associated with YouTube librarians must be given a great deal of consideration and potential discussion.

\section{REFERENCES}

Absher, L. (n.d.). The Lipstick Librarian. Retrieved June 3, 2008, from http://www.lipsticklibrarian.com/

Adams, K. (2000). Loveless Frump as Hip and Sexy Party Girl: A Reevaluation of the Old-Maid Stereotype. The Library Quarterly, 71, 287-301.

Comscore.com ( October 11, 2006). ComScore Data Confirms Reports of 100 Million Worldwide Daily Video Streams from YouTube.com in July 2006. Retrieved June 3, 2008, from http://www.comscore.com/press/release.asp?press=1023

Cloud, J. (2006, December 25). The YouTube Gurus. Time, 66-74.

Credaro, A.B. Warrior Librarian Weekly. Retrieved June 3, 2008, from http://www.warriorlibrarian.com/ 
Cullen, J. (2000). Rupert Giles, the Professional-image Slayer. American Libraries. 42. Retrieved May 20, 2008 from Academic Search Premier database in EBSCOhost.

DeCandido, G. (1999). Bibliographic Good vs. Evil in Buffy the Vampire Slayer. American Libraries, 30, 44-48.

Dickinson, T. (2002). Looking at the Male Librarian Stereotype. The Reference Librarian 78, 97-110.

Fagan, J. (2002). Students' Perceptions of Academic Librarians. The Reference Librarian 78, 131-148.

Hall, S. (1997). Representation: Cultural Representations and Signifying Practices. Thousand Oaks, Ca. Sage Publications.

Kniffel, L. (2005). What We Can Learn From Junk TV—and Vice Versa. American Libraries 36, 1, 44.

McLuhan, M. (1964). Understanding Media; the Extensions of Man. New York: Macgraw-Hill.

Radford, M., \& Radford, G. (2003). Librarians and Party Girls; Cultural Studies and the Meaning of the Librarian. The Library Quarterly 73: 54-69.

Riccio, H. (2004). Image and the Librarian. AALL Spectrum Magazine 8, 7, 10-11.

Searle, M. (2008). Old Maids, Policeman, and Social Rejects: Mass Media Representations and Public Perceptions of Librarians. Electronic Journal of Academic and Special Librarianship 9. Retrieved May 20, 2008 from http://southernlibrarianship.icaap.org/content/v09n01/seale_m01.html

Seidl, A. (Director). (2007). The Hollywood Librarian: A Look at Librarians Through Film [Motion Picture]. United States: American Library Association.

Trier, J. (2007). 'Cool' Engagements With YouTube: Part 1. Journal of Adolescent \& Adult Literacy 50, 408-412.

Webb, P. (2007). YouTube and Libraries: It Could Be a Beautiful Relationship. College and Research Libraries News 68, 354-355.

Yeagley, B. (1999). Shelving, Stamping, and Shushing: Librarians in the Movies. MLS Thesis. Kent State University.

\section{YOUTUBE FILMS CITED}

tv12673. (2006). Angry Librarian [video]. Retrieved May 23, 2008 from http://youtube.com/watch?v=7XvAakX_cQ

hbwdotcom. (2008). Best of 07-Baresoles in the Library 4 of 6 [video]. Retrieved May 23, 2008 from http://youtube.com/watch?v=PDCptIIlcA4 
IDTVshow. (2008). Bill Hutkins: Library Cop--Part 1 [video]. Retrieved May 23, 2008 from http://youtube.com/watch?v=Qr2Tg8AljrO

jamoe868. (2006). Crazy Librarian [video]. Retrieved May 23, 2008 from http://youtube.com/watch?v=kQHEoFSpjd4

saehae. (2007). hails is a sexy librarian [video]. Retrieved May 23, 2008 from http://youtube.com/watch?v=6UHs1HZgKQo\&feature=related

fossilbeach. (2007). Hot Miami Librarian [video]. Retrieved May 23, 2008 from http://youtube.com/watch?v=gZJn54uwndQ

pumpkinbasket. (2007). Hot Sexy Librarians getting peed on [video]. Retrieved May 23, 2008 from http://youtube.com/watch?v=TIPAT8dKkYI

ErikTheLibrarian. (2008). Is Life Worth Living? Erik The Librarian Ep. 1 [video]. Retrieved May 23, 2008 from http://youtube.com/watch?v=vpjT_c_QFX8

HauntedLove. (2007). Librarian [video]. Retrieved May 23, 2008 from http://youtube.com/watch?v=Ne_WXP7IUWM

Dorisfilms. (2008). Librarian [video]. Retrieved May 23, 2008 from http://youtube.com/watch?v=cAHkPIKzPOO

PMLariat. (2008). Librarian: Heel Lift, a Quick View [video]. Retrieved May 23, 2008 from http://youtube.com/watch?v=2pmz74T9l2o

cozinho1. (2006). The Librarian [video]. Retrieved May 23, 2008 from http://youtube.com/watch?v=p4fil1LIUgo

rahostetler. (2006). The Librarian [video]. Retrieved May 23, 2008 from http://youtube.com/watch?v=yEmjRH9I-KO

YourCrazy. (2006). The Librarian [video]. Retrieved May 23, 2008 from http://youtube.com/watch?v=AhWkbicYtoE

Tuzenbach. (2007). The Librarian: A Mockumentary [video]. Retrieved May 23, 2008 from http://youtube.com/watch?v=FqWQQ6w3HTM

f4tk1dx. (2006). The Librarian Dialogues [video]. Retrieved May 23, 2008 from http://youtube.com/watch?v=hoHdTpJReUk\&feature=related

PrankVote. (2007). Library Porno [video]. Retrieved May 23, 2008 from http://youtube.com/watch?v=KYD-JK1La-k

scooterk. (2006). Library? Security? Dancing Girls [video]. Retrieved May 23, 2008 from http://youtube.com/watch?v=6Bmu1fdDL6k 
florganadorf. (2007). Library Security Guard [video]. Retrieved May 23, 2008 from http://youtube.com/watch?v=Igv5IPpEQdQ

letterboxmedia. (2006). Ninja Librarian [video]. Retrieved May 23, 2008 from http://youtube.com/watch?v=pyLTqBARFt8

Prangstgrup. (2006). Prangstgrup Library Musical - Reading on a Dream PRANK!! [video]. Retrieved May 23, 2008 from http://youtube.com/watch?v=-mUyvaPtsJw

PeterMEUK. (2007). Rappelling in the UK Library [video]. Retrieved May 23, 2008 from http://youtube.com/watch?v=ochhLnAYehE

brycebommer. (2007). Sex in the Library [video]. Retrieved May 23, 2008 from http://youtube.com/watch?v=jyXVY7G9wpc

soccerstar4ever. (2007). Sexy Librarian ;) [video]. Retrieved May 23, 2008 from http://youtube.com/watch?v=hw_HFbwxxgE

starfishmann. (2007). Sexy Librarians v2 [video]. Retrieved May 23, 2008 from http://youtube.com/watch?v=08nJKaLNutw 